\title{
PHENOTYPIC AND GENETIC TRENDS FOR SOME MILK YIELD TRAITS OF EGYPTIAN BUFFALOES

\author{
El-Arian, M. N. ${ }^{\star}$; N. A. Shalaby ; A. S. Khattab ${ }^{\star *}$; S. A. Darwish*** \\ and R. H. Abou-Gamous \\ * Animal Production Dept., Fac. of Agric., Mansoura University \\ ** Animal Production Dept., Fac. of Agric., Tanta University. \\ Animal Production Inst., Agric. Res. Center.
}

\begin{abstract}
A total number of 600 female buffaloes, having 3321 lactation records, from first to tenth parity, kept at three experimental farms (Mahalet Mousa, El-Nataf ElGaded and El-Nataf El-Kadem), belonging to the Animal Production Research Institute, Ministry of Agriculture, Cairo, Egypt, during the period from 2000 to 2007 were used to study genetic and phenotypic progress, achieved by the Mixed Model Equations (MME) for the Best Liner Unbiased Prediction. The number of sires were 66 sires and the average number of daughters per sire were 12.50. Mixed Model Least square analyzed was used to estimate fixed effects of month and year of calving, parity and farm on (total milk yield (TMY), lactation period (LP), fat yield (FY), protein yield (PY), lactose yield (LY) and somatic cell count (SCC). Data were analyzed using Multi Trait Animal Model to estimate genetic parameters and breeding values. Unadjusted means of TMY, LP, FY, PY, LY and SCC were $2070 \mathrm{~kg}, 223 \mathrm{~d}, 164.4 \mathrm{~kg}$ $89.5 \mathrm{~kg}, 128.2 \mathrm{~kg}$ and $204.8 \times 10^{-3} \mathrm{cells} / \mathrm{ml}$, respectively. Heritability estimates ( $\pm \mathrm{SE}$ ) of TMY, LP, FY, PY, LY and SCC were $0.41 \pm 0.06,0.31 \pm 0.07,0.20 \pm 0.09,0.19 \pm$ $0.03,0.22 \pm 0.10$ and $0.06 \pm 0.03$, respectively. Estimates of genetic correlations among milk yield traits were positive and ranged from 0.18 to 0.8 , while the genetic correlation between SCC and all milk traits are negative and ranged from -0.18 to 0.66. Phenotypic correlation among all traits studied were the same direction of genetic correlations. The range of expected sire breeding values (SBV's) for milk traits were $1418 \mathrm{~kg}, 13.27 \mathrm{~d}, 178 \mathrm{~kg}, 91 \mathrm{~kg}, 139 \mathrm{~kg}$ for TMY, LP, FY, PY and LY, respectively.

Annual phenotypic change for TMY, LP, FY, PY and LY were positive and highly significant, being $74.20 \mathrm{~kg}, 18.84 \mathrm{~d}, 7.48 \mathrm{~kg}, 2.89 \mathrm{~kg}$ and $2.10 \mathrm{~kg}$, respectively. The corresponding annual genetic change for the same above traits averaged 3.70 $\mathrm{kg}, 0.55 \mathrm{~d}, 0.90 \mathrm{~kg}, 0.60 \mathrm{~kg}$ and $0.54 \mathrm{~kg}$, respectively. Positive genetic and phenotypic trends in the present results indicated that the selection plan of that herds was use the best sires, so that in the next generation will excepect genetic improvement for traits under investigation except the SCC of lactating Egyptian buffaloes at these herds.
\end{abstract}

\section{INTRODUCTION}

A goal of dairy cattle breeders is to increase genetic merit for milk production and composition by using selection of animals and estimate genetic change from time to time. Also, to determine the effectiveness of breeding programs, genetic trends in dairy cattle population must be monitored (Hintz, et al., 1978).

For determining the effect of selection in a population over the years, it is necessary to know phenotypic and genetic trends. Genetic and phenotypic changes in the performance traits of dairy cattle are the ultimate indicator of progress in a herd. The genetic gain per unit of time is also required for taking certain changes in the management practice and breeding 
policy. The measure of genetic and environmental changes from field data have problems since many factors are confounded with both genetic and environmental changes. In this respect, Henderson et al. (1959) indicated that a maximum likelihood methods using repeatability of cow's records to separate genetic and environmental effects. In Egypt, few studies were carried out to estimate phenotypic and genetic trend for Egyptian buffaloes. Mourad (1984) used three methods to estimate genetic improvement per generation for 305 day milk yield: (1) regression coefficients of generation means on generation means, (2) doubling regression coefficients of sire generation means on sire generation number and (3) regression coefficients of individual records on generation numbers. Khattab and Mourad (1992) and Fooda et al. (2010) estimated genetic trends for milk traits by using BLUP.

The aims of the present study were to (1) estimate phenotypic and genetic parameters for TMY, LP, FY,PY, LY and SCC* $10^{-3} \mathrm{cells} / \mathrm{ml}$ milk and (2) phenotypic and genetic change for these traits in a closed three herds of Egyptian buffaloes kept at Melalet Mousa Farm, station belonging to Animal Production Research Institute, Ministry of Agriculture, Cairo, Egypt.

\section{MATERIALS AND METHODS}

Data in the present study were obtained from lactation records of Egyptian buffaloes kept at three Experimental farms (Mahalet Mousa, ElNataf El-Gaded and El-Nataf El-Kadem), belonging to the Animal Production Research Institute, Ministry of Agriculture, Cairo, Egypt. Data comprised 600 buffaloes having 3321 records from 1 to 10 lactation during the period from 2000 to 2007.

Animals were mainly grazed on Egyptian clover (Trifolium alexandrinum) during December to May. They were fed on concentrate mixture along with rice straw and limited amount of clover hay when available during the rest of the year. Cows were machine milked twice daily (at 7 am and $4 \mathrm{pm}$ ). Milk yield was recorded weekly. Cows were naturally mated until 2002 and artificially insemination after that. Assignment of sires to cows was at random. Heifers were served for the first time when they reached 24 month or $350 \mathrm{~kg}$. Genetic analysis include the sires which had more than 5 daughters were 66 sire and the average of daughters per sire was 12.50 .

Preliminarily analyses of the data were made by using Statistical Analysis System (SAS,2001) version 8.2 for Windows to study the fixed effects of month and year of calving, parity and farm and random effect of sire on TMY, LP, fat FY, PY and yield LY.

The following linear mixed model was used:

$$
Y_{i j k l m n}=U+S_{i}+M_{j}+Y_{k}+P_{I}+F_{m}+e_{i j k l m n}
$$

Where:

$Y_{\mathrm{ijk} k m n}=$ the performance of observations;

$\mathrm{U}=$ the overall mean;

$S_{i}=$ the random effect of the $i$ th sire of cow;

$M_{j}=$ the fixed effect of the month of calving, $j=1,2,3, \ldots$ and 12;

$Y_{k}=$ the fixed effect of year of calving, $k=2000,2001, \ldots$ and 2007; 
$\mathbf{P}_{\mathbf{I}}=$ the fixed effect of parity, $i=1,2, \ldots$.

$\mathbf{F}_{\mathrm{m}}=$ the fixed effect of farm, $m=1,2$ and 3

$\mathrm{e}_{\mathrm{ijk} \mid m n}=$ random effect of errors.

In addition, all traits studied are analyzed by multiple trait derivate Free Restricted Maximum Likelihood ( MTDFREML) according to Boldman et al. (1995) using multiple trait animal model.

Multiple Trait Animal Model (MTAM):

All traits studied were analyses by using MTAM. The model included the random effects of individuals and errors and the fixed effects of month and year of calving, parity and farm. In matrix notation the multiple traits animal model used was:

$$
\mathbf{Y}=\mathbf{X b}+\mathbf{Z g}+\mathbf{e}
$$

Where:

$\mathrm{Y}=$ observation vectors of animals;

$b=$ vector of common fixed effects.

$\mathrm{g}=$ animal genetic vector and

$\mathrm{e}=$ residual effect vectors and $\mathrm{Z}$ is incidence matrices.

Estimates of heritability, genetic correlation, phenotypic correlation were estimated from MTAM according to Boldman et al. (1995). MTAM were used to estimate BLUP values for sires.

The Mixed model equations (MME) for the best linear unbiased estimator (BLUE) for estimate function (b) and for the Best Linear Unbiased Prediction (BLUP) of (a) according to Morde (1996).

The annual phenotypic change for different traits studied were computed as the regression coefficients of the traits values on the year of calving, after adjusting the records for the non genetic effects (month and year of calving, parity and farm). Trends in transmitting abilities of sires for different traits studied were estimated from the regression estimates of sire breeding values on each year of birth as described by Hintz et al. (1978).

\section{RESULTS AND DISCUSSION}

\section{Unadjusted means:}

Means, standard deviations (SD) and coefficients of variation (CV \%) of different studied traits are presented in Table 1. The present mean of TMY $2070 \mathrm{~kg}$ was higher than those reported by El-Arian et al. (2001) 1270 and Khattab et al. (2010) $1591 \mathrm{~kg}$ working on Egyptian buffaloes, while, the present mean was lower than that found by Badran et al. (2002) $2256 \mathrm{~kg}$ working on another herd of Egyptian buffaloes. The present mean of LP (223 d) was lower than those found by El-Arian et al. (2001) 312 and Badran et al. (2002) 314.05 day for Egyptian buffaloes. Overall means of fat yield and protein yield were $164.4 \mathrm{~kg}$ and $89.5 \mathrm{~kg}$, respectively (Table 1). The present means were higher than those reported by Tonhati et al. (2011) $90.1 \mathrm{~kg}$ and $56.9 \mathrm{~kg}$, respectively. While the present means are lower that those reported by Rosati and Van Vleck (2002) $197 \mathrm{~d}$ working on Murrah buffaloes. Means of lactose, total solids and somatic cell counts were $128.2 \mathrm{~kg}$ and $204.8 \times 10$ ${ }^{3}$ cells $/ \mathrm{ml}$, respectively (Table 1 ). 
The coefficient of variability ranged from 28.8 to $59.9 \%$ (Table 1 ). The higher estimates for fat, protein and lactose yield were due to higher variation between animals. The difference between the present means and those reported in other studies for dairy cows could be possibly due to one or more of the following reasons (1) the herds were raised under different climatic and managerial conditions, (2) herd could possibly different than the other by genetic and phenotypic various and (3) different methods and models of analysis were used.

Table 1: Means, standard deviations (SD) and coefficients of variation (CV\%) for total milk yield, lactation period, fat yield, protein yield, lactose yield and somatic cell counts in Egyptian buffaloes.

\begin{tabular}{|l|c|c|c|}
\hline \multicolumn{1}{|c|}{ Trait } & Mean & SD & CV\% \\
\hline Milk yield, kg & 2070 & 712.0 & 34.4 \\
\hline Lactation period, d & 223 & 64.2 & 28.8 \\
\hline Fat yield, kg & 164.4 & 98.5 & 59.9 \\
\hline Protein Yield, kg & 89.5 & 46.7 & 52.1 \\
\hline Lactose yield, kg & 128.2 & 51.8 & 40.4 \\
\hline $\begin{array}{l}\text { Somatic cell counts } \\
\left(\text { SCC }^{*} 10^{-3}\right) \text { cells/ml milk }\end{array}$ & 204.8 & 71.3 & 34.8 \\
\hline
\end{tabular}

\section{Non genetic aspects}

Month of calving had a significant effect on TMY, LP, FY and PY $(P<$ 0.05 or $P<0.01$ ), while had no significant effect on LY and SCC (Table 2). Similar results are reported by Mourad et al. (1991) working on Egyptian buffaloes and Khan et al. (2007) on Nili-River buffaloes .

Year of calving had significant effect on TMY, LP, FY, PY and LY ( $P$ $<0.01$ ), while had no significant effect on SCC (Table 2). These results are agree well with the findings on Egyptian buffaloes are reported by Mourad (1984), Mourad et al. (1991), Badran et al. (2002) and Khattab et al. (2003) found that year of calving have a significant influence $(P<0.01)$ on milk traits. The present results show that there is no specific trend for the effect of year of calving on milk traits. The effect of year of calving may be due to changes in production from year to another can be attributed to changes in herd size, age of animals, improved management practices introduced from year to another and phenotypic trend.

Parity or lactation order had a significant effect on TMY, LP, FY, PY and $\operatorname{LY}(P<0.05$ or 0.01$)$, Table 2. Similar results were obtained by Mourad et al. (1991) and Khattab et al. (2010) using other sets of data Egyptian buffaloes. A significant effect of parity on milk traits is logically due to the increase in body weight combined with advancing age and to the full development of the secretary tissue of the udder. At such time animal is mature as body weight and size fully developed accompanied by increase in the size and function of digestive and circulatory system, mammary gland, and the other body systems. Therefore, that amount of feed intake and feed utilization is greatly increased associated with increased efficiency of milk synthesis and secretion of the udder tissue. 
Table 2: Least squares analysis of variance for factors affecting different studied traits in Egyptian buffaloes.

\begin{tabular}{|c|c|c|c|c|c|c|c|}
\hline \multirow{2}{*}{ S.O.V } & \multirow{2}{*}{ D.f } & \multicolumn{6}{|c|}{ F- Values } \\
\hline & & TMY & LP & FY & PY & LY & SCC \\
\hline Among Sires & 65 & 4.78 & 3.74 & 2.22 & 2.94 & 2.71 & 0.66 \\
\hline $\begin{array}{l}\text { Among Month of } \\
\text { Calving }\end{array}$ & 11 & $2.79^{\star \star}$ & $5.88^{\star \star}$ & $2.14^{*}$ & $2.15^{\star}$ & 1.18 & 0.92 \\
\hline $\begin{array}{l}\text { Among Year of } \\
\text { Calving }\end{array}$ & 7 & $23.94^{\star *}$ & $33.39^{* *}$ & $38.94^{\star *}$ & $22.56^{\star *}$ & $29.32^{\star \star}$ & 1.14 \\
\hline Among Parity & 9 & $35.32^{\star \star}$ & $11.49^{\star *}$ & $4.15^{\star \star}$ & $4.53^{\star \star}$ & $3.03^{*}$ & 1.00 \\
\hline Between Farms & 2 & $30.85^{\star \star}$ & $7.09^{\star \star}$ & $66.70^{\star \star}$ & $143.10^{\star \star}$ & $81.16^{\star \star}$ & 0.42 \\
\hline Reminder & 3226 & 367668 & 3397 & 66.96 & 14.53 & 18.17 & 3109 \\
\hline
\end{tabular}

* $P<0.05$

Farm had a significant effect on TMY, LP, FY, PY and LY $(P<0.01)$, Table 2. Similar results are reported by Abdel-Salam et al. (2009) working 3526 lactation records of 2179 buffaloes in 51 herds at 8 governorates under four production systems, found that the highest least squares means of total milk yield was $2044 \mathrm{~kg}$ milk in Fayoum governorate, while the lowest was $1444 \mathrm{~kg}$ milk in Ismalia governorate. The least squares means of total milk yield of commercial, experimental, flying and small holder production systems was 1844, 1328, 1993 and $1770 \mathrm{~kg}$, respectively.

Generally, the differences in milk traits among farms might be due to differences in management practices and differences in genetic merit of the stock raised at each farm.

\section{Genetic parameters}

Estimates of heritability ( \pm SE) for TMY, LP, FY, PY, LY and SCC by using Mult Trait Animal Model are presented in Table 3. Heritability estimate for TMY was $0.41 \pm 0.06$. The heritability values of TMY was higher and in the same time it is higher than those obtained by using animal model by Tonhati et al. (2000) 0.35 on Murrah Buffaloes in Brazil and Khattab et al. (2003) 0.91 on Egyptian buffaloes. Heritability estimates for lactation period was $0.31 \pm 0.07$ (Table 3).

Heritability estimates $( \pm$ SE) for FY, PY and LY were $0.20 \pm 0.09,0.19 \pm$ 0.03 and $0.22 \pm 0.10$, respectively (Table 3 ). Similar results were reported by Aspilcueta-Borquis et al. (2010) estimated genetic parameters for fat (FY 305), protein (PY 305), milk fat and protein percentages, by using Bayesian methodology. The posterior means of heritability distributions for FY 305, PY 305, fat percentage and protein percentage were $0.23,0.33,0.39$ and 0.26, respectively. They added that, milk yield and milk components have enough genetic variation for selection purposes.

The high and moderate heritability estimates for TMY, LP, FY, PY and LY suggested that efforts could be made to bring about improvement in those important economic traits through individual selection as well as better management practices. In other words, the genetic improvement in milk production and it is composition can be achieved through selection breeding program.

Estimate of heritability for SCC was $0.06 \pm 0.03$ (Table 3). Low heritability estimate for SCC indicate that this trait is affected mainly by environmental factors, such as cleaning, improvement of feeding, management and milking the cow three times per day. The present $h^{2}$ estimate of SCC is lower than those reported by 
several investigators (Morde et al., 1998; Koivula et al., 2005; and El-Arian and ElAwady, 2008), ranging from 0.15 to 0.26 in different dairy cattle breeders.

Table 3: Estimates of heritability $\left(\mathrm{h}^{2}\right)$ diagonal with standard errors (SE), genetic correlations (below diagonal), with standard errors (SE) and phenotypic correlations ( above diagonal) among different traits studied.

\begin{tabular}{|c|c|c|c|c|c|c|}
\hline Traits & MY & LP & FY & PY & LY & SCC \\
\hline MY & $\mathbf{0 . 4 1 \pm 0 . 0 6}$ & 0.73 & 0.64 & 0.63 & 0.53 & -0.02 \\
\hline LP & $0.75 \pm 0.07$ & $\mathbf{0 . 3 1 \pm 0 . 0 7}$ & 0.42 & 0.32 & 0.20 & -0.01 \\
\hline FY & $0.18 \pm 0.09$ & $0.30 \pm 0.10$ & $\mathbf{0 . 2 0 \pm 0 . 0 9}$ & 0.89 & 0.78 & -0.02 \\
\hline PY & $0.30 \pm 0.10$ & $0.27 \pm 0.10$ & $0.80 \pm 0.10$ & $\mathbf{0 . 1 9 \pm 0 . 0 3}$ & 0.20 & -0.12 \\
\hline LY & $0.37 \pm 0.09$ & $0.23 \pm 0.10$ & $0.25 \pm 0.09$ & $0.30 \pm 0.04$ & $\mathbf{0 . 2 2 \pm 0 . 1 0}$ & -0.20 \\
\hline SCC & $-0.27 \pm 0.10$ & $-0.20 \pm 0.10$ & $-0.18 \pm 0.10$ & $-0.40 \pm 0.21$ & $-0.66 \pm 0.24$ & $\mathbf{0 . 0 6}+\mathbf{0 . 0 3}$ \\
\hline
\end{tabular}

In general, it is observed that heritability estimates for all milk traits were moderate, expect for SCC and this may be allowed to improve them through selection and improving environment conditions.

Genetic correlation between total milk yield and lactation period was positive and high $(0.75 \pm 0.07)$ Table 3 , indicating that high yielding buffaloes are also having the longer LP. This correlation suggests that selection for higher yielding cows would cause a correlated increase in their lactation period. Khattab and Mourad (1992) and El-Arian et al. (2001) arrived to the same conclusion.

Genetic correlation between TMY, and each of fat yield, protein yield, and lactose yield were positive and being $0.18 \pm 0.09,0.30 \pm 0.10$, and $0.37 \pm 0.09$, respectively (Table 3). Estimates of genetic correlations between milk yield and milk composition are similar to those that can be found in the literature for dairy cattle. Large estimates for genetic correlations between milk, fat, protein, and lactose are commonly reported for dairy cattle (Rosati and Van Vleck, 2002; Hussein, 2004 and Ghonem, 2002). The present results indicated that milk yield could be used as a good indicator for the genetic values of the other milk traits ( $F Y$, PY, LY and LP). Also, the present results indicated that the higher productive cows were lactating for longer time and selection for higher milk yield brings correlated response for lactation period.

The negative genetic correlations between SCC and milk traits which ranged from -0.66 to -0.18 (Table 3 ). Similar results were reported by El-Awady (2009) found that genetic correlation between milk yield and SCC was -0.35 . The present results indicated that selection for milk yield and milk composition will decrease somatic cell counts, which indicate the health of udder.

The present results suggest that selection for high milk yield will be associated with genetic improvement in milk composition and decrease somatic cell counts.

\section{Predicted breeding values (PBV's)}

Estimation of predicting breeding values from sires (PBV's), range and accuracy ( $r$ ) for TMY, LP, FY, PY, LY, and SCC are presented in Table 4. The expected breeding values showed large differences among sires for TMY, LP, FY, PY, and LY. The range of PBV's were $1418 \mathrm{~kg}, 13.27 \mathrm{~d}, 178 \mathrm{~kg}, 91 \mathrm{~kg}$, and $139 \mathrm{~kg}$ for TMY, LP, FY, PY, and LY, respectively. Similar results are obtained by different 
authors working on different breeds of buffaloes. In this respect, EL-Chaife (1981) working on two herds of Egyptian buffaloes, reported that the range of breeding values for 100 day milk yield and lactation period were large and ranged from -56 to $88 \mathrm{~kg}$ for 100 day milk yield and from -39 to $32 \mathrm{~d}$ for lactation period. Khattab and Mourad (1992) estimated sire breeding values by using BLUP without relationship between sires, on 1180 first lactation records of Egyptian buffaloes, found that sire transmitting ability ranged from -147 to $154 \mathrm{~kg}$ for TMY and from 31 to 20 d. for LP.

Also, Khattab et al. (2003) working on 1226 normal first lactation records of Egyptian buffaloes. They found that predicted breeding values of sires (SBV), ranged between (-211 and $407 \mathrm{~kg})$ and $(-26$ and $33 \mathrm{~d})$ for TMY and LP, respectively. Also, the same authors concluded that the high accuracy of predicted breeding values of sires, then it is necessary to depend on sire for estimated breeding values. Also the accuracy of predicted breeding value of dams, indicate that dams are less important than sires and cows for estimating breeding values. Addition they concluded that the importance of cow, since it gave the higher range of breeding values for TMY and LP than dams breeding values, thus range of breeding values the next generation in maternal line would place emphasis on good genetic maternal effects in addition to good estimates of breeding values. In this respect, Khattab et al. (2010) working on another set of Egyptian buffaloes, found that the range of sires breeding values for TMY and LP were $1020 \mathrm{~kg}$ and 64 d, respectively.

Table 4: Estimates of sire breeding values, it is standard errors and accuracy for milk traits in Egyptian buffaloes.

\begin{tabular}{|l|c|c|c|c|}
\hline \multirow{2}{*}{ Traits } & \multicolumn{4}{|c|}{ SBV's } \\
\cline { 2 - 5 } & Min. \pm SE & Max. \pm SE & Range & Accuracy \\
\hline TMY, kg & $-578 \pm 144$ & $840 \pm 156$ & 1418 & 0.45 to 0.57 \\
\hline $\mathrm{LP}, \mathrm{d}$ & $-4.42 \pm 1.7$ & $8.85 \pm 1.54$ & 13.27 & 0.44 to 0.59 \\
\hline $\mathrm{FY}, \mathrm{kg}$ & $-85 \pm 9.3$ & $93 \pm 10$ & 178 & 0.41 to 0.49 \\
\hline $\mathrm{PY}, \mathrm{kg}$ & $-47 \pm 7.0$ & $44 \pm 7.30$ & 91 & 0.46 to 0.50 \\
\hline $\mathrm{LY}, \mathrm{kg}$ & $65 \pm 19$ & $74 \pm 19$ & 139 & 0.35 to 0.39 \\
\hline SCC ${ }^{*} 10^{-3}$ & $-1.16 \pm 1.24$ & $8.03 \pm 1.20$ & 9.19 & 0.36 to 0.41 \\
\hline
\end{tabular}

SBV's: sires breeding values.

The present result also, show that the range of sire breeding values for SCC was small being $\left(9.19 * 10^{-3}\right)$ cells $/ \mathrm{ml}$ of milk.

The present results indicated that sires had positive breeding values for milk yield are also positive values for LP, FY, PY and LY and lower for SCC. Therefore, selection of these sires with improve the environmental factors will improve milk yield and it is components.

\section{Annual Phenotypic and genetic progress.}

Annual phenotypic change for milk traits studied were presented in Table 5. Annual phenotypic changes for TMY, LP, FY, PY and LY are positive and highly significant and being $74.20 \mathrm{~kg}, 18.84 \mathrm{~d}, 7.48 \mathrm{~kg}, 2.89 \mathrm{~kg}$ and $2.10 \mathrm{~kg}$, per year, respectively. Similar results are reported by many authors working on buffaloes in different countries. In this respect, Mourad (1984) with first lactation of Egyptian buffaloes, found positive annual 
phenotypic change being $6.64,17 \mathrm{~kg}$ and $2.9 \mathrm{~d}$ for 70 day milk yield, 305 day milk yield and lactation period, respectively.Khattab and Mourad (1992) working on 1180 first lactation records of Egyptian buffaloes, during the period from 1966 to 1987. They reported that the annual phenotypic trend for total milk yield and lactation period were $16.20 \mathrm{~kg}$ and $-5.7 \mathrm{~d}$, respectively.

Table 5: Estimates of phenotypic change ( $b \pm$ S.E.) and annual of genetic gain with standard errors (SE) for TMY, LP, FY, PY and LY in Egyptian buffaloes.

\begin{tabular}{|l|c|c|}
\hline \multicolumn{1}{|c|}{ Traits } & b \pm S.E. & Genetic trend \pm S.E \\
\hline \hline$T M Y, k g$ & $74.20 \pm 8.29^{* *}$ & $3.70 \pm 0.09$ \\
\hline $\mathrm{LP}, \mathrm{d}$ & $18.84 \pm 3.20^{* *}$ & $0.55 \pm 0.028$ \\
\hline $\mathrm{FY}, \mathrm{kg}$ & $7.48 \pm 1.20^{* *}$ & $0.90 \pm 0.01$ \\
\hline $\mathrm{PY}, \mathrm{kg}$ & $2.89 \pm 1.00^{* *}$ & $0.60 \pm 0.02$ \\
\hline $\mathrm{LY}, \mathrm{kg}$ & $2.10 \pm 0.80^{\star *}$ & $0.54 \pm 0.07$ \\
\hline${ }^{* \star} \mathbf{P}<\mathbf{0 . 0 1}$. &
\end{tabular}

In Portuguese, Ramos et al. (2006) working on Murrah Buffaloes during the period from 1982 to 2003. They estimated genetic and phenotypic trends were estimated by regressions of the dependant variables on year of the animals calving, based on two methods: linear regression and articulated polynomial regression. They found that phenotypic trend for milk yield was $27.75 \mathrm{~kg} /$ year.

The present estimates indicate that phenotypic improvement in milk yield and it is composition was achieved during the period of the study. Also, the present results indicated that the differences in performance between years are mainly due to different nutritional, climatic conditions and management practices prevalent over different times.

Estimates of annual genetic change for milk traits studied are presented in Table 5.Annual genetic progress for milk traits are positive and significant averaged $3.70 \mathrm{~kg} / \mathrm{y}, 0.55 \mathrm{~d} / \mathrm{y}, 0.90 \mathrm{~kg}, 0.60 \mathrm{~kg}$ and $0.54 \mathrm{~kg}$ for TMY, LY, FY, PY and LY, respectively. On other words, the regression of the sire breeding values on time indicated an increase of $3.70 \mathrm{~kg} / \mathrm{y}, 0.55 \mathrm{~d} / \mathrm{y}, 0.90$ $\mathrm{kg}, 0.60 \mathrm{~kg}$ and $0.54 \mathrm{~kg}$ per year for total milk yield, lactation length, fat yield, protein yield and lactose yield, respectively. Similar results were reported by many authors working on different breeds of dairy cattle in different countries (Hintz et al., 1978; Khattab and Mourad, 1992; El-Arian et al., 2001; Razmkabir et al., 2006 and Herintgstad and Larsgaid, 2010).

On Egyptian buffaloes, Mourad (1984)estimated average genetic improvement per generation by using three methods with the first lactation records, found that they ranged from $4.1 \mathrm{~kg} / \mathrm{year}$ to $11.8 \mathrm{~kg} / \mathrm{year}$ for 305 day milk yield and from $-2 \mathrm{~d} /$ year to $6 \mathrm{~d} /$ year for lactation length. Khattab and Mourad (1992) estimated annual genetic trends for total milk yield and lactation period by regression breeding values of sires on year of calving. They found that a decrease of $-1.60 \mathrm{~kg}$ and $-0.40 \mathrm{~d}$ for total milk yield and lactation period, respectively. Also, Fooda et al. (2010) on five farms of Eg2yptians buffaloes, collected from El-Nattafe El-Gidid (NG), El-Nattafe ElKadim (NK), Mahalet Mousa (MM), Gemiza (G) and Sids (SS), reported that 
the annual genetic trend for total milk yield were $0.60 \mathrm{~kg}, 0.57 \mathrm{~kg}, 0.57 \mathrm{~kg}$, $0.58 \mathrm{~kg},-016 \mathrm{~kg}$ and $0.54 \mathrm{~kg}$ for the five farms, respectively. They concluded that differences between the experimental stations may be attributed to different nutritional level, climatic conditions, management practices in different herds and the interaction between genetic and environmental factors.

In addition, Abdel-Salam et al. (2009) estimated genetic trend for productive traits on Egyptian buffaloes by using simulation technique, simulation with assumed mean (0) and variance (1). Four different populations sizes (Z) 10000, 25000, 50000 and 100000 animals were obtained. Four generations of progeny were obtained by selection of sires and dams of the next generations. Mating ratio (males: females) were designed to different form 1:25 to 1:100 in natural mating (NM) and from 1:1000 to 1:5000 in artificial insemination (Al). They found that genetic gain increased significantly $(P<0.05)$ with increase in generation number $(G)$ being 282, 389, 457 and $488 \mathrm{~kg}$ milk/y for G1, G2, G3 and G4, respectively. The annual genetic gain ranged from $64 \mathrm{~kg} / \mathrm{y}$ for $Z=10000$ to $73 \mathrm{~kg} / \mathrm{y}$ for $Z=$ 100000. Increasing nucleus size $(P)$ from 0.05 to 0.10 increased genetic gain significantly $(P<0.05)$ from 390 to $418 \mathrm{~kg} / \mathrm{y}$.

\section{CONCLUSION}

The present results show that the sires used in the period of the study are superiority genetic values. This could be due to selection of sires, dams and cows and used proven sires and progeny test. On the other words, positive genetic gain for milk yield, lactation period, fat yield, protein yield and lactose yield indicated that the programs of selection of that herds was to selection the best sires, for the next generation would lead to higher genetic improvement for milk traits, which is the target of the breeders. In addition, the results showed that improvement of milk production through selection with environmental conditions improved is possible. Genetic progress can be achieved if the farms adopts tests for the genetic evaluation of sires. Therefore, more research work in this respect is needed by using a large data sets.

\section{REFERENCES}

Abdel-Salam, S.A.M., Abou-Bakr, Ibrahim, M.A.M Sadek R.R. and AbdelAziz, A.S. (2009). Estimation of breeding values of total milk yield of Egyptian buffalo under different production systems. Proceedings ICAR $36^{\text {th }}$ Session, Technical series 13: $167-172$.

Aspilcueta-Borquis, R.R. Araujo Neto, F.R. Baldi, F. Bignardi, A.B.; Albuquerque, L.G. and Tonhati, H. (2010). Genetic parameters for buffalo milk yield and milk quality traits using Bayesian inference analysis of then relationships. Genetic and Molecular Research. 9 (3): $1636-1644$.

Badran, A. E.; El-Barbary, A.; Mahdy, A.E. and Assar, G.M. (2002) . Genetic and non-genetic factors affecting the lifetime production traits in Egyptian buffaloes. Buffalo Journal., 18 (2): 235-241. 
Boldman, K.G., Kriese, L.A., Van Vleck, L.D. and Kachman, S.D. (1995). A manual for use of MTDFREL. Department of Agriculture, Agricultural Research service, Lincoln, pp. 120.

El-Arian, M.N. and El-Awady, H.G. (2008).Assessment of the genetic relationships between udder health and milk production traits in relation to selection for improving resistance to clinical mastitis in Friesian cows in Egypt. J. Agric. Sci. Mansoura Univ., 33: 181 - 192.

El-Arian, M.N., El-Ayek, M.Y., Khattab, A.S. and Abou-Gamous, R.H (2001). Estimates of genetic parameters and genetic trends of some milk production traits in a commercial herd of Holstein Friesian cows in Egypt. J. Agric. Sci. Mansoura Univ., 26: 1975-1987.

El-Awady, H.G. (2009). Calculation of the economic values for some udder health traits to estimate the profitability of the selection indices for dairy cows in Egypt. J. Agric. Res. Kafrelsheikh University, 35: 384 - 401.

El-Chaife, O.M. (1981). Studies on cattle (Cows and buffaloes) sire evaluation and genetic parameters of partial lactation, dry period and service period. M.Sc., Thesis, Faculty of Agric., Alex., Egypt.

Fooda, T., Mourad, K.A. and Gebreel, I.A. (2010). Phenotypic and genetic trends for milk production in an experiment stations buffalo herd. Proceedings $9^{\text {th }}$ world Buffalo congress Buenos Aires 21 (1): $403-407$

Ghonem, E.M. (2002). Estimation of sire breeding values for milk traits in a herd of Friesian cow. M.Sc. Thesis, Fac. of Agric Tanta Univ., Egypt.

Henderson, C.R., Kempthorne, O., Seacle, S.R. and Vokorsgh, C. (1959). The estimation of environmental and genetic trends from records subject to culling. Biometrics, 12: $192-218$.

Herintgstad, B. and Larsgaid, A.G. (2010). Correlated of selection responses for female fertility after selection for high protein yield and low mastitis frequency in Norwegian Red cows. J. Dairy Sci., 93: 5970 - 5976.

Hintz, R.L. Everett, R.W. and Van Vleck, L.D. (1978). Estimation of genetic trends from cow and sire evaluations. J. Dairy Sci., 61: 607- 613.

Hussein, A.M. (2004). Genetic and phenotypic studies for Friesian cows in Egypt. Ph.D. Thesis, Faculty of Agric. Mansoura Univ., Egypt.

Khan, M.S. Faiz-ul-Hassan, Saif-ur-Rehman, M. Hyder, A.U. and Bajwa, I.R. (2007).Genetic control of milk yield from lactations of different duration in Nili-Ravi buffaloes. Archiv fur Tierzucht. 50 (3): 227-239.

Khattab, A. S, El-Awady, H.G., El-Arian, M.N. and Kawther, A. Mourad (2003). Genetic analysis of some performance traits using an animal model in a herd of Egyptian Buffaloes. Egyptian J. Anim. Prod. 40: 15 26.

Khattab, A.S.; Kawther, A.M.; El-Habiab, S. and Awad, S. (2010). Estimation of genetic parameters and breeding values for some productive traits on Egyptian buffaloes. Revista Veterinaria. 21: Suppl. 1, 1046 - 1048.

Khattab, A.S. and Mourad, Kawther, A. (1992).Estimation of genetic parameters and genetic trends for some milk traits in a herd of Egyptian buffaloes. Egyptian J. Anim. Prod., 29 (2): 173 - 184. 
Koivula, M., Mäntysaari, E.A. Negussie, E. and Serenius, T. (2005). Genetic and phenotypic relationships among milk yield and somatic cell count before and after clinical mastitis. J. Dairy Sci. 88: 827- 833 .

Morde, R.A. (1996). Linear Models for the prediction of animal breeding values. CAB International, UK, PP 184.

Morde, R.A., Swanson, G.J.T. and Winter, M.S. (1998). Genetic parameters and evaluations for somatic cell counts and its relationship with production and type traits in some dairy breeds in the United Kingdom. Anim. Sci. 66: 569-579.

Mourad, Kawthar, A., Mohamed, M.M. and Khattab, A.S. (1991).Genetic parameters for milk production traits in a closed herd of Egyptian buffaloes. Egypt J. Anim. Prod., 28 (1): 11 - 20.

Mourad, Kawthar A. (1984). Genetic improvement in a herd of Egyptian buffaloes. Ph.D. Thesis, Faculty of Agriculture, Moshtoher, Banha Univ., Egypt.

Ramos, A. de A. Malhado, C.H.M. Carneiro, P.L.S. Goncalves, H.C. and Azevedo, D.M. (2006). Phenotypic and genetic characterization of the milk yield and calving interval in buffalo of the Murrah breed. Pesquisa Agropecuaria Brasileira. 41 (8): 1261 - 1267.

Razmkabir, M., Nejati, J., Mordadi, S., Rashudi, A and Sayadnejed, M. (2006). Genetic and environmental trends for production traits in Holstein cattle of Iran. The $57^{\text {th }}$ Annual Meeting for the European association of Animal production, Antalya, Turkey, P. 24.

Rosati, A. and Van Vleck, L.D. (2002). Estimation of genetic parameters for milk, fat, protein and mozzarella cheese production for the Italian river buffalo Bubalus bubalis population. Livest. Prod. Sci., 74 (2): 185-190.

SAS Procedures Guide ( 2001) . Version 8.2, 2001. SAS Inst ., Inc., Cary, NC.

Tonhati, H., Vasconcellors, F.B. and Albuquerque, L.G. (2000). Genetic aspects of productive and reproductive traits in a Murrah buffalo herd in Sao Paulo, Brazil. J. of Anim. Breeding and Genetics ., 177 (5): 331 336.

Tonhati, H. Lima, A.L.F. Lanna, D.P.D. Camargo, G.M.F. de; Baldi, F. Albuquerque, L.G. de and Montrezor, J.M.C.D. (2011). Milk fatty acid characterization and genetic parameter estimates for milk conjugated linoleic acid in buffaloes. Journal of Dairy Research. 78 (2): 178 183. 


\section{El-Arian, M.N. et al.}

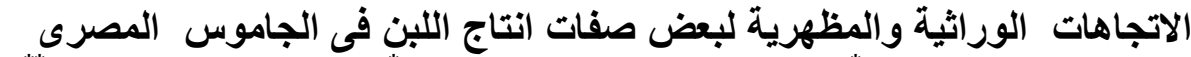

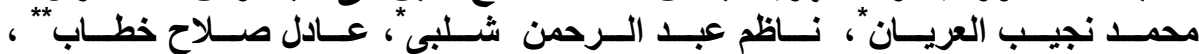

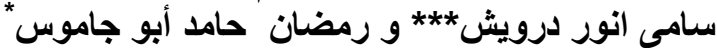

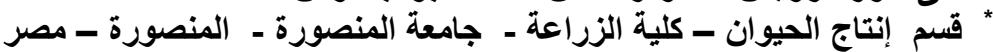

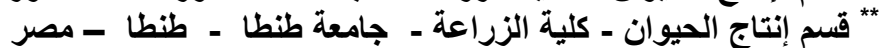

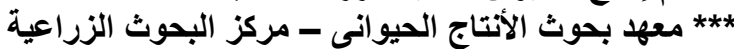

استخدم فى هذه الدراسة بيانات سجلات 3321 من الجاموس المصرى و التىى توجد في ثنلاث

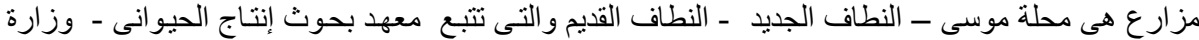

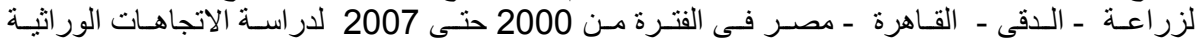

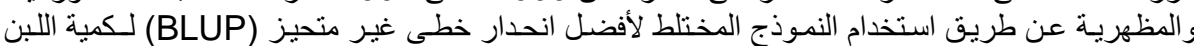

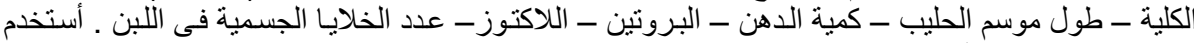

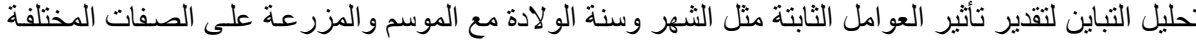

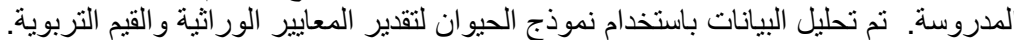

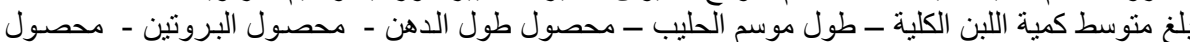
اللاكتوز - عدد الخلايا الجسمية 2070 كجم - 223 يوم -164.4 كجم - 164 - 89.5 كجم - 128.2 كجم 204.78 ألف خلية/مللى لبن على التو الىى. لكي.

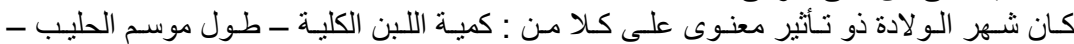

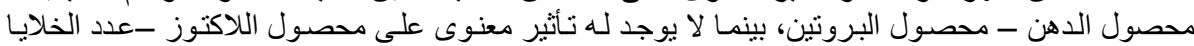

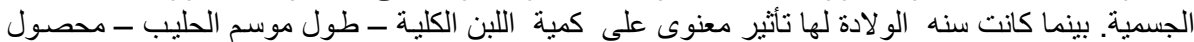

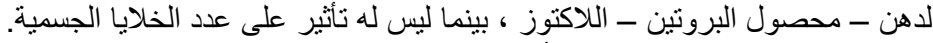

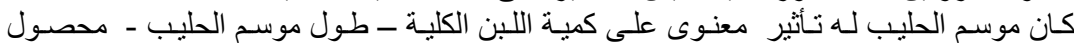

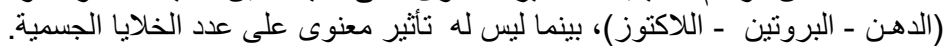

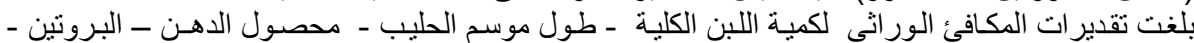

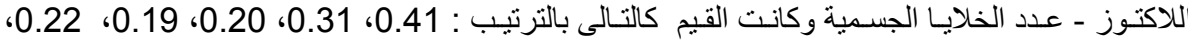
0.06 على التو الىى.

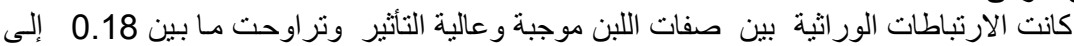

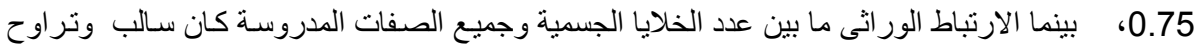

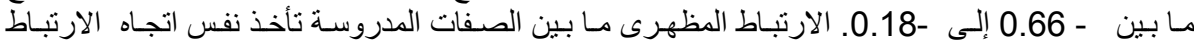

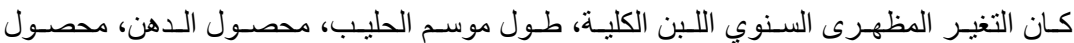

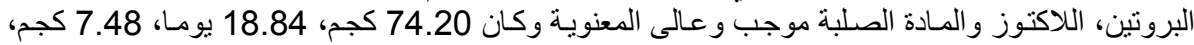

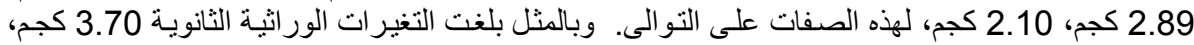

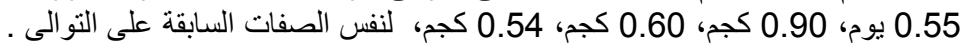

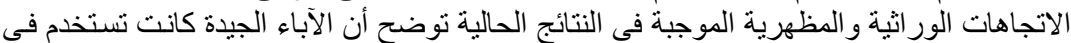

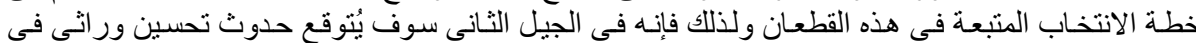

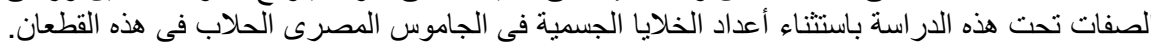

كلية الزراعة - جامعة المنصورة كلية الزراعة - جامعة كفر الثيخ - جليخ
قام بتحكيم البحث

أ. أد / السعيد زهرى عوده البحث

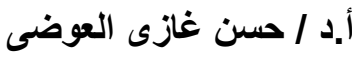

